\title{
PENGARUH LAMA FERMENTASI TERHADAP KADAR PROTEIN TEMPE BIJI DURIAN
}

\author{
Agnes Yuantin Maharani ${ }^{1)}$, Nasrul Rofiah Hidayati ${ }^{2)}$, Sri Handayani ${ }^{3)}$, Dewi Endri Astuti ${ }^{4}$, \\ Ria Nopida ${ }^{5)}$, Syaiful Fachrurazi ${ }^{6)}$ \\ 1,2,3) Pendidikan Biologi IKIP PGRI Madiun, \\ 4,5) Pendidikan Matematika IKIP PGRI Madiun \\ ${ }^{6)}$ Pendidikan Fisika IKIP PGRI Madiun \\ Jalan Setiabudi No. 85 Madiun \\ email: phbdikipmdn2016@gmail.com \\ Diterima 20 Agustus 2016, Disetujui 30 September 2016
}

\begin{abstract}
Tempeh is a food that is produced from the fermentation process by Rhizopus mold. Tempe derived from soy that contains carbohydrates and proteins needed during fermentation. In addition to soy other materials that could be used adalag Biju durian. Flour starch content of $43.6 \mathrm{~g} / 100 \mathrm{~g}$ durian seeds while the protein at $2.6 \mathrm{~g} / 100 \mathrm{gr}$ durian seeds. Tempeh from durian seeds are foods produced from the fermentation of Rhizopus fungi same group as soybeans. Through the fermentation process, the components of the complex nutrients durian seeds ingested by fungi with the enzymatic reaction and the resulting compounds are more modest. This study aims to determine levels of protein contained in each fermentation. The research method using the experimental method Completely Randomized Design (CRD) is a variation of fermentation time of 30 hours, 40 hours and 50 hours. Collecting data by calculating the protein content through formol titration method. Analysis of data using analysis of variance (ANOVA) two ways through SPSS version 23.0 which shows the difference in the protein content of the soybean quality with a significant level of $0.018<0.05$, which means the length of fermentation. The highest protein content of fermentation 30 hours. The protein content of fermentation time low of 50 hours.The results of this study support the existence of tempeh produkrivitas and durian seeds in the world food industry.
\end{abstract}

Keywords: Protein test, Seeds durian tempeh, Fermentation

\section{PENDAHULUAN}

Pangan merupakan kebutuhan utama bagi manusia. Diantara kebutuhan yang lainnya, pangan merupakan kebutuhan yang harus dipenuhi agar kelangsungan hidup seseorang dapat terjamin. Masalah laju pertumbuhan penduduk di Indonesia semakin hari semakin meningkat sehingga semakin meningkat pula kebutuhan akan pangan. Sehingga mengakibatkan krisis kekurangan pangan dan kondisi gizi masyarakat.

Pangan mempunyai peranan yang sangat penting dalam mengurangi masalah kekurangan gizi dan kesehatan masyarakat, karena seluruh anggota masyarakat tanpa terkecuali merupakan konsumen pangan.
Berbagai jenis pangan diantaranya berasal dari bahan pangan hewani maupun nabati yang mengandung karbohidarat, protein, lemak, vitamin, mineral dan air yang diperlukan oleh tubuh sebagai sumber energi sehingga kebutuhan gizi dalam tubuh dapat terpenuhi untuk melakukan aktitivitas sehari-hari.

Salah satu usaha untuk mengurangi masalah kekurangan gizi adalah dengan memperkenalkan dan membudidayakan makanan bergizi tinggi yang terjangkau daya beli masyarakat dan dapat diterima oleh konsumen. Salah satunya adalah tempe, yaitu makanan warisan budaya asli dari Indonesia yang saat ini sedang diupayakan sebagai makanan produk yang 
dipersembahkan untuk dunia. Tempe biji durian berasal dari biji durian yang dihasilkan dari fermentasi kapang.

Tempe banyak diproduksi oleh industri kecil dan rumah tangga dengan kisaran produksi $10 \mathrm{Kg}-2$ ton per hari. Hingga saat ini terdapat lebih dari 100,000 produsen tempe yang tersebar di berbagai provinsi di Indonesia. Konsumsi tempe memberikan kontribusi minimal $10 \%$ dari total protein harian, sementara telur $1.25 \%$, daging $3.15 \%$ dan sereal sekitar $60 \%$. Data BPS (2012) menunjukkan bahwa konsumsi tempe masyarakat Indonesia secara ratarata mencapai $7 \mathrm{~kg} / \mathrm{kapita} / \mathrm{tahun}$.

Di Indonesia, tempe merupakan sumber protein tinggi yang harga per satuan unit lebih murah apabila dibandingkan dengan sumber protein asal hewani seperti daging, susu, dan telur. Tempe biji durian adalah makanan yang dihasilkan dari proses fermentasi kapang golongan Rhizopus. Melalui proses fermentasi, komponenkomponen nutrisi yang kompleks pada biji durian dicerna oleh kapang dengan reaksi enzimatis dan dihasilkan senyawa-senyawa yang lebih sederhana. Pada saat fermentasi selesai, akan menghasilkan produk tempe biji durian mentah yang berwarna putih menarik dengan bau khas durian.

Pengaruh lama fermentasi tempe biji durian ini perlu di uji kadar protein Dengan adanya uji kadar protein diharapkan masyarakat mengetahui kadar protein yang terkandung dalam tempe biji durian dari lama fermentasi. Hasil uji kadar protein yang dilakukan dapat diaplikasikan di dunia industri makanan sebagai makanan bergizi, kaya protein dan diminati seluruh lapisan masyarakat.

\section{METODE}

Penelitian uji kadar protein dilaksanakan di Laboratorium SMKN 3 Kimia Madiun. Waktu untuk penelitian dilaksanakan pada bulan Agustus sampai bulan September 2016.

Metode penelitian yang digunakan adalah variasi lama fermentasi 30 jam, 40 jam, 50 jam untuk menentukan kadar protein yang dikandungnya.

\section{Pembuatan Tempe Biji Durian}

Biji durian dibersihkan terlebih dahulu. Bi.ji durian kemudian dijemur hingga kering untuk menghindari tumbuhnya kapang. Biji durian dicuci terlebih dahulu sebelum direbus. Biji durian direbus kurang lebih 30 menit dengan tujuan agar kulit terluarnya dapat dikupas. Biji durian dicuci agar lendirnya hilang. Biji durian diiris secara membujur dan tipis-tipis. Biji durian yang telah diiris direndam selama 12-18 jam. Biji durian kemudian dicuci kembali dengan tujuan untuk mengurangi rasa masam yang ditimbulkan oleh aktivitas fermentasi selama perendaman. Biji durian dikukus selama kurang lebih 60 menit. Biji durian yang telah dikukus dibiarkan sampai dingin. Biji durian yang telah dingin ditaburi ragi tempe dan tepung beras dan diaduk secara merata. Tempe biji durian dibungkus dengan daun pisang. Kemasan tempe biji durian diberi lubang agar udara dapat masuk sehingga pertumbuhan kapang tidak terganggu dengan cara ditusuk-tusuk pada permukaan kemasan. Tem[pe biji durian disimpan pada ruang tertutup selama 48 jam. Tempe biji durian telah jadi

\section{Uji Kadar Protein}

Persiapan sampel dengan cara menimbang 2 g sampel dengan gelas piala, menambahkan $40 \mathrm{ml}$ aquades dan mengaduk sampai larutan homogen. Memasukkan kedalam labu ukur $50 \mathrm{ml}$, dan tambahkan aquades sampai tanda tera (tepat $50 \mathrm{ml}$ ), kocok hingga homogen. Menyaring larutan tersebut, sehingga filtrate hasil saringan siap dianalisa.

Kemudian prosedur analisa dengan cara mengambil $5 \mathrm{ml}$ sampel atau larutan protein dipindahkan ke dalam labu Erlenmeyer dengan menggunakan pipet volume, menambahkan $10 \mathrm{ml}$ aquades dan 0,2 ml kalium oksalat jenuh, menambahkan 0,5 tetes indikator PP $1 \%$ (kocok), kemudian mentitrasi larutan tersebut 
dengan larutan $\mathrm{NaOH} 0,05 \mathrm{~N}$ dari biuret sampai larutan berubah warna dari "tak berwarna" menjadi "merah muda". Mencatat volume larutan $\mathrm{NaOH} 0,05 \mathrm{~N}$ yang dibutuhkan $\left(\mathrm{T}_{1}\right)$, selanjutnya menambahkan $1 \mathrm{ml}$ larutan formalin (kocok, larutan menjadi bening), mentitrasi kembali sampai larutan berubah warna menjadi merah muda, dan catat kembali volume $\mathrm{NaOH} 0,05 \mathrm{~N}$ yangdibutuhkan $\left(\mathrm{T}_{2}\right)$. Melakukan prosedur analisa tersebut, tiap sempel dengan empat kali pengulangan. Selanjutnya menuliskan hasil pengamatan kedalam data pengamatan. Melakukan pada prosedur tersebut untuk blanko $(10 \mathrm{ml}$ sampel diganti dengan $10 \mathrm{ml}$ aquades)

Teknik analisis data penelitian ini meliputi analisis uji kadar protein. Uji kadar protein dilakukan di laboratorium SMK Negeri 3 Kimia Madiun. Uji kadar protein menggunakan metode titrasi formol.Teknik analisis data pada penelitian ini menggunakan anava satu jalur dengan SPSS (stastical product and service solution) versi 23.

\section{HASIL DAN PEMBAHASAN}

\section{Kadar Protein}

Berdasarkan penelitian yang ada didapatkan data tertinggi yaitu pada fermentasi 50 jam sebesar 0,6177\%.dan kadar protein terendah yaitu pada fermentasi 30 jam sebesar 0,2189\%.

Hasil analisis data menggunakan analisis varian (anava) dua jalur melalui SPSS variasi 23.0 yang menunjukkan perbedaan kadar protein terhadap kualitas tempe dengan taraf signifikan $0,018<0,05$ yang berarti lama fermentasi dan meode pembungkusan berpengaruh terhadap kadar protein, setelah itu dilanjutkan dengan uji DMRT (Duncan Multiple Range Test).

Perhitungan kadar protein pada tempe biji durian yang diberi perlakuan lama fermentasi menggunakan metode titrasi formol. Hasil analisis anava dua jalur dengan taraf signifikasi 0,05 diperoleh angka probabilitas (sig) sebesar 0,018 <
0,05 yang berarti terdapat perbedaan kandungan protein terhadap tempe.

Hasil analisis anava dua jalur menunjukkan taraf signifikaan 0,05 diperoleh angka probabilitas (sig) sebesar $0,018<0,05$ yang berarti terdapat perbedaan fermentasi. Perlakuan dengan fermentasi tempe biji durian 50 jam memiliki rerata kadar protein paling tinggi yaitu $0,6177 \%$.Sedangkan fermentasi tempe biji durian 30 jam memiliki rerata kadar protein paling rendah yaitu $0,2189 \%$.

Menurut Hesseltine (1965 dalam Deliani 2008) penyebab terjadinya penurunan kadar protein akibat fermentasi adalah jamur Rhizopus oligosporus bersifat proteolitik dan ini penting dalam pemutusan protein. Jamur ini akan mendegradasi protein selama fermentasi menjadi peptide dan seterusnya menjadi senyawa $\mathrm{NH}_{3}$ dan $\mathrm{N}_{2}$ yang hilang melalui penguapan. Dengan semakin lama fermentasi berarti semakin lama kesempatan jamur mendegradasi protein, sehingga protein yang terdegradasipun semakin banyak, akibatnya protein tempe semakin menurun. Pendapat ini juga didukung oleh penelitian Morita dan Handoyo (2006) yang menyatakan bahwa protein akan terdegradasi atau dihidrolisis selama proses fermentasi. Kadar protein akan naik hingga 24 jam, kemudian mengalami proses pendewasaan akibat adanya enzim, karena lama fermentasi mengakibatkan produksi enzim yang lebih rendah ditunjukkan oleh perubahan warna tempe menjadi coklat, sedangkan fermentasi yang belum mengalami proses pendewasaan atau matang akan berwarna putih dan memiliki produksi enzim yang maksimum.

Semakin lama fermentasi dapat menurunkan kadar protein karena selama proses fermentasi, enzim yang dihasilkan oleh kapang dapat menghidrolisis protein menjadi asam amino yang dapat digunakan yang dapat dimanfaatkan kapang untuk pertumbuhan dan perkembangan (Kustanto, 2013). Hasil hidrolisis tempe oleh enzim protease menghasilkan protein tempe dapat 
diubah menjadi senyawa asam amino, nukleotida, dan berbagai ragam peptidapeptida pendek yang mempunyai rasa gurih. Hasil hidrolisat tempe oleh enzim protease dibuat sebagai bahan penyedap rasa pengganti MSG (Machin, 2012).

Selain lama fermentasi, penurunan kadar protein pada tempe disebabkan oleh beberapa faktor yaitu penambahan bahan dan pengukusan (pemanasan) (Lusiyatiningsih, 2014). Semakin lama perendaman biji menyebabkan penurunan kadar protein, ini disebabkan peningkatan kadar air selama proses pengolahan dan fermentasi. Pada perebusan terjadi hidrasi karena air mengalami difusi ke dalam biji kacang. Perebusan kacang-kacangan dapat menyebabkan beberapa perubahan kualitas, baik secara fisik, biokimia, maupun nilai gizinya (Pramita, 2008).

Menurut Suprapti (2003) bahwa pembungkusan tempe menggunakan daun sama halnya dengan menyimpannya dalam ruang gelap (salah satu syarat ruang fermentasi), mengingat daun yang tidak tembus pandang. Disamping itu aerasi dapat tetap berlangsung melalui celah-celah pembungkus yang ada.

Pernyataan ini didukung oleh Sayuti (2015) penyebab kadar protein adalah bahan kemasan yang berasal dari daun kedap cahaya (tidak tembus cahaya), sirkulasi udara (aerasi) dapat terjadi dengan baik melalui celah-celah pada daun sehingga oksigen lebih mudah masuk ke dalam kemasan. Dengan sirkulasi udara yang baik menyebabkan kelembaban dapat terjaga dengan baik. Ketiga faktor tersebut akan mendukung pertumbuhan kapang selama proses fermentasi. Sedangkan kemasan plastik tidak kedap cahaya, sirkulasi udara tergantung pada jumlah lubang yang diberikan, begitu juga kelembaban tergantung pada sirkulasi udara akibat dari pemberian lubang pada kemasan.

Berbeda halnya dengan tempe biji durian, berdasarkan hasil yang diperoleh diketahui bahwa semakin lama waktu fermentasi maka kadar protein tinggi. Lama fermentasi yang baik untuk pembuatan tempe biji durian yaitu 50 jam.

Hasil penelitian ini diaplikasikan untuk menunjang produktivitas serta eksistensi tempe biji durian dimasa yang akan datang.

\section{SIMPULAN}

Berdasarkan penelitian yang telah dilaksanakan dapat diambil kesimpulan:

1. Ada pengaruh lama fermentasi terhadap kadar protein tempe biji durian.

2. Hasil penelitian berupa uji kadar protein tempe biji durian untuk mendukung produktivitas dan eksistensinya dimasa yang akan datang.

\section{DAFTAR PUSTAKA}

Cahyadi, W. (2007). Kedelai Khasiat Dan Teknologi. Jakarta: Bumi Aksara.

Deliani. (2008). Pengaruh Lama Fermentasi Terhadap Kadar Protein, Lemak, Komposisi Asam Lemak Dan Asam Fitat Pada Pembuatan Tempe. Tesis. Medan: Sekolah Pascasarjana Universitas Sumatera Utara Medan

Handoyo, T., Morita, M. (2006). Structural And Functional Properties of Fermented Soybean (Tempeh) By Using Rhizopus Oligosporus. International Journal of Food Properties, 9: 347-355, 2006

Kusnanto, F., Sutanto, A., Mulyani, H. (2013). Pengaruh Waktu Fermentasi Terhadap Kadar Protein Dan Daya Terima Tempe Dari Biji Karet (Hevea Brasiliensis) Sebagai Sumber Belajar Biologi Sma Pada Materi Bioteknologi Pangan. Pendidikan Biologi FKIP Universitas Muhammadiyah Metro Lampung (Online).(http://fkip.ummetro.ac.id, diunduh pada 20 Juni 2016). 